Available Online at http://journal.unismuh.ac.id/index.php/otoritas

Otoritas : Jurnal Ilmu Pemerintahan, 8 (2), October 2018, 98-109

\title{
The Rise of Political Warfare: Russian New Way of War against the West and the Western Counteractions
}

\author{
Hasan Suzen*) \\ Beyond the Horizon International Strategic Studies Group, Da Vincilaan 1, 1932 Zaventem, Belgium.
}

Received: 28 May 2018; Revised: 18 July 2018; Accepted: 20 July 2018

\begin{abstract}
Since the outbreak of the Ukraine crisis, the world has observed a comprehensive Russian political warfare, which has had destabilising consequences and as well as wide-ranging implications for international security, in particular for Europe. On the other hand, in the aftermath of the Cold War, the West mostly focus on public diplomacy and strategic communication rather than political warfare. This change creates a gap in all features of political warfare and makes the West weak to political warfare waged by particularly one-man ruled states. In this respect, firstly, I will define political warfare in the continuum of peace and war. Then, I will develop a new conceptual framework which provides an interdisciplinary approach to understand the specifics of political warfare against the West and its counteractions. To explore how and why the West has failed in countering and undermining political warfare employed by especially one-man ruled states, I will explain the origin and evolution of Russian political warfare and particularly highlight the Ukraine Crisis as a turning point of Russian political warfare which has been evolving since the 1900s. Finally, I will propose ways and means to explain how to counter political warfare using hybrid tactics in the future.
\end{abstract}

Keywords: Political warfare; hybrid warfare; Russia; NATO; European Union

How to Cite: Suzen, H. (2018). The Rise of Political Warfare: Russian New Way of War against the West and the Western Counteractions. Otoritas : Jurnal Ilmu Pemerintahan, 8 (2), 98-109.

Permalink/DOI: https://doi.org/10.26618/ojip.v8i2.1314

${ }^{*}$ Corresponding Author.

E-Mail : hasan.suzen@behorizon.org

Copyright (C) 2018, Otoritas : Jurnal Ilmu Pemerintahan, ISSN: 2088-3706 (Print), ISSN: 2502-9320 (Online) 


\section{INTRODUCTION}

International security experts, academics, practitioners, and officials highlight in recent years that changing security landscape in the eastern and southern flank strengthens the EU's and NATO's prerequisite to reinforce not only readiness but also responsiveness as well as update their soft power (Ratsiborynska, 2018).

Since the eruption of the Ukraine crisis, the world has witnessed a welldeveloped Russian political warfare strategy and the hybrid model, utilised by Kremlin, which has had to destabilise consequences and as well as wide-ranging implications for international security, in particular for Europe. While the concept seems like a novelty, in fact, Putin has built up current Russian political warfare strategy against the West on valuable historical background and experiences dates back to the Bolsheviks and the Soviet Union (Dickey, 2015).

On the other hand, in the aftermath of the Cold War, the West mostly focus on public diplomacy and strategic communication to influence the foreign audience rather than political warfare (Boot \& Doran, 2013). From my perspective, this shift creates a gap in all aspects of political warfare and makes the West vulnerable to political warfare waged by particularly one-man ruled states and non-state enemies.

Therefore, it is high time to analyse the reasons behind the West, notably NATO's and the EU's, poor reaction against new forms of political warfare as well as to find ways to improve their response capacity and capabilities through a variety of mechanisms. In this paper, the first in a series of three articles, I will define political warfare and its new forms such as hybrid methods and blurring war, which is to be the basis for the rest of the study. Then, I will develop a new conceptual framework which provides an inter- disciplinary approach to understand the specifics of political warfare against the West and to explore how and why the West has failed in countering and undermining political warfare employed by especially one-man ruled states. Finally, I will propose ways and means that I will go into detail in my further studies to explain how to counter political warfare in the future.

As most scholars refer to the oftenquoted passage of Clausewitz, I also prefer to start with the very famous statement of him. War is a mere continuation of policy by other means (Clausewitz, trans. by Rapoport, 1982). Some scholars such as Kennan (1948) who have Clausewitzian perspective, define the political warfare as the logical application of Clausewitz's doctrine in time of peace (Dickey, 2015). Seabury \& Codevilla (1989) extend these arguments by adding propaganda, agents of influence, sabotage, coups de main, economic sanctions, and support for foreign groups to political warfare means. To Gray (2009), Peace and war are different phases of statecraft-distinctive, but essentially united and permanently connected.

Thus, we could come to realise that political warfare is political because it is a strategy that intentionally avoids an open war, but at the same time, it is warfare because it is covertly violent and adversarial. With its nature, political warfare has a distinct character from other forms of warfare, as it uses less-bloody means. Even though one of the core principles of political warfare is to avoid conventional war, it is still a form of war between diplomacy and conventional war.

It must be noted that the use of force or credible threat of violence is a necessary step for pursuing political warfare. With regard to this argument, Seabury \& Codevilla (1989) highlight that political warfare may serve as a surrogate for actual war, but it does not work without actual force backing it up. This is because, as 
Art (2009) claims, military power undergirds the other instruments of statecraft. In this respect, we could argue that activities conducted during political warfare campaign could easily continue in support of conventional war especially in shaping the conflict environment.

A different approach is evident in some other scholars such as Hoffman (2014) who argues in a Clausewitzian sense, all kinds of war could be seen as political warfare. They claim that political warfare is not new, especially by quoting to Sun Tzu's Art of War in 512 BC and Thucydides' History of the Peloponnesian War in 433 BC (Smith, 1989). But Codevilla (2009), a political warfare theorist, emphasises that the transition from political warfare to peace or war is not clear. Contrary to the scholars like Hoffman, I would argue that political warfare, in the continuum of peace and war, could be seen as an early stage of conventional war to shape the conflict environment, or as an admixture integrating all means of national power which occupies a space between war and peace as Sun Tzu stated the highest excellence is to subdue the enemy's army without fighting at all (Sun \& Grif- fith, 1971).

Needless to say, Clausewitz's work has enjoyed a diverse readership. Among them, early communist thinkers such as Engels, Lenin, and Stalin (even Mao) were also familiar with Prussian way of war, and no doubt that they were fascinated by Clausewitz who claims that war is a real political instrument and the servant of politics. In this respect, we could hold that their understanding of the links between politics and war was identical to Marxist theory (Dexter, 1950).

From my point of view, to understand the drivers of Russian political warfare, we should examine the longstanding Russian imperial identity, sketching from its expansion in the 16th century through 19th centuries and the records of the Soviet Union (Oliker, Crane, Schwartz, \& Yusupov, 2009). Particularly during the Cold War era -and now as well-, its imperial identity has a crucial role in framing Russian political warfare campaign in its periphery. Therefore, Russian analysts and accounts characterise this periphery as "buffer-zone", namely countries that were formerly part of the Soviet Union (Trenin, 2011). In conjunction with this

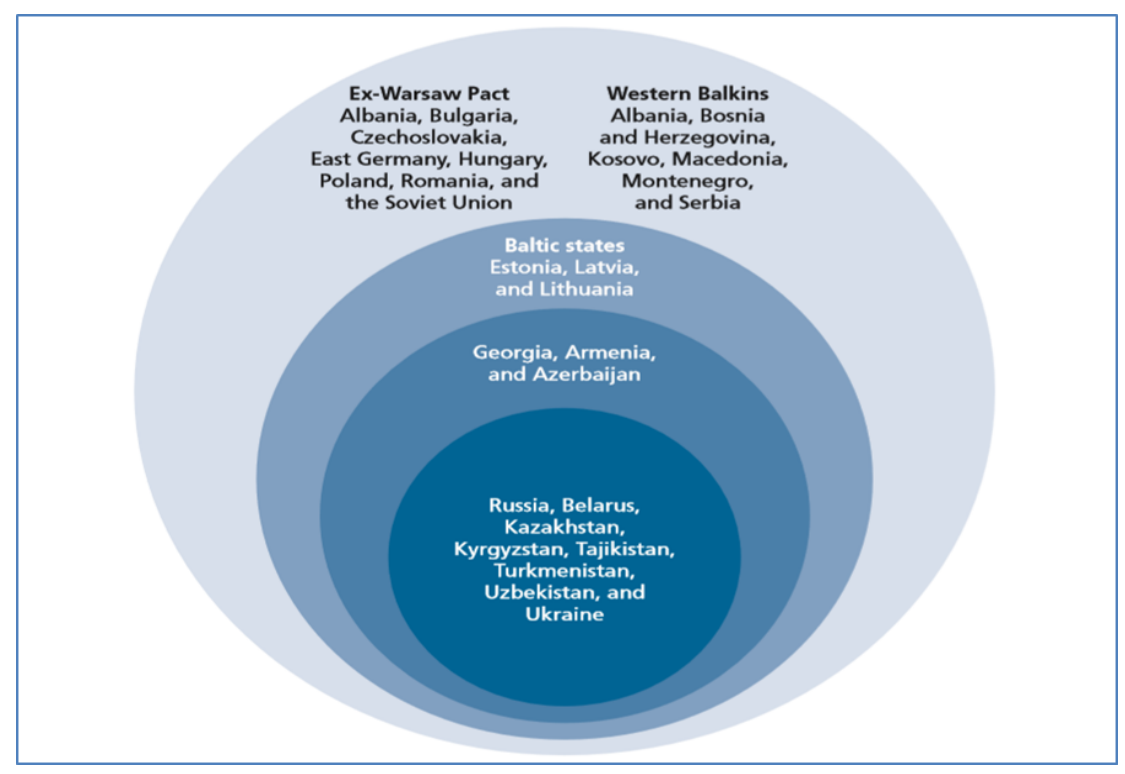

Figure 1. Russia's Desired Spheres of Influence Source: Radin \& Reach, 2017 
Available Online at http://journal.unismuh.ac.id/index.php/otoritas

Otoritas : Jurnal Ilmu Pemerintahan, 8 (2), October, 2018, 101

mindset of Hill \& Gaddy (2013) also note that Vladmir Putin highlighted derzhavnost-the belief that Russia is always destined to be a great power exerting its influence abroad as shown in figure 1.

\section{RESEARCH METHODS}

The series of three articles will answer the research questions by testing the hypothesis using a comparative study methodology. A number of methods will be used to address the research questions and to test the proposed hypotheses.

\section{Extensive Investigation of Databases, Archival and Academic Materials}

In this part, I will identify and categorise political warfare actions and counteractions which have impacts on the political environment. Primary sources will include declassified documents, diplomatic correspondence, instructions, and case analysis. Secondary sources will consist of academic studies, interpretations, and reflections on the historical and current events associated with Putin, the EU, and NATO actions and counteractions.

Firstly, a qualitative analysis of Rus- sian political warfare will be conducted by identifying the evolution of Russian political warfare from Bolsheviks to the Putin's era.

Then I will identify the rise of Russia since 2000 and the Russian Grand Strategy with a special focus on Putin's Era. I will examine the utmost important drivers of the rise of Russia such as Gerasimov doctrine and military transformation, the economic boom in the form of earnings from oil and gas exports. Then the case of Georgia War in 2008, and the frozen conflicts such as Abkhazia, South Ossetia and Nagorno-Karabakh, East Ukraine, and Transnistria will be presented as evidence that Russia redeveloped political warfare capacity and capabilities. After building this historical background, I will investigate one of the core cases of this study: Russian hybrid tactics during the Ukrainian crisis as a new generation political warfare.

Secondly, I will explore the EU and NATO responses to political warfare employed by Putin. I will highlight why the EU and to some extent NATO responses based on appeasement encouraged Putin's aggression, and how and why the

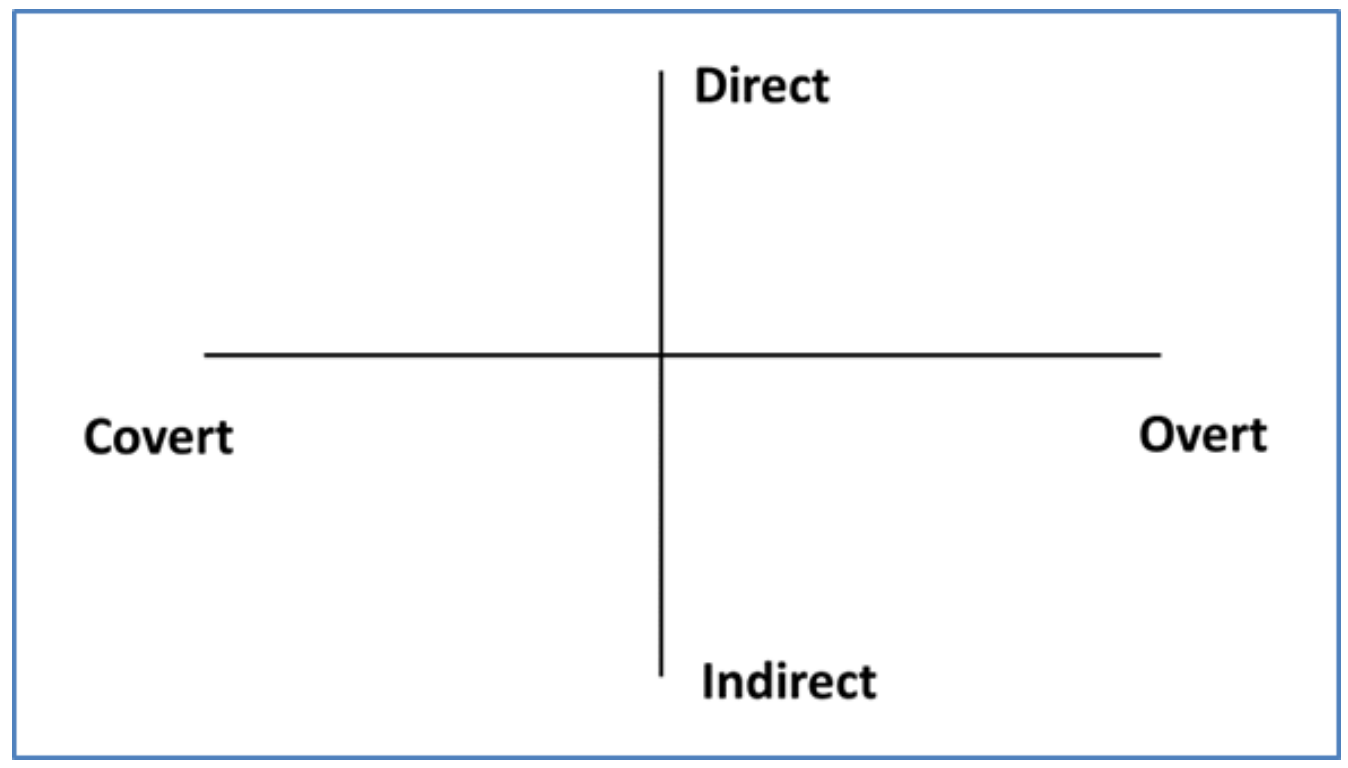

Figure 2. Political Warfare Spectrum

Source: Steward, 2015 
efforts of both organisations for deescalating the crisis and conflict, and for countering political warfare have failed or were ineffective.

I will use Steward (2015)'s analytical tool, which extends Kennan (1948)'s overt-covert spectrum with directindirect approaches, to assess political warfare actions and counteractions as shown in Figure 2.

\section{Application of Theoretical Approaches to Political Warfare}

In parallel, I will use the lenses of sociology, psychology, economics and political science in the following articles of this study. As group mobilisation or collective action is very important to achieve political warfare objectives (Blackstock, 1964; Seabury \& Codevilla, 1989), I will apply Social Movement Theory to political warfare actions and counteractions of all parties to understand the collective dynamics of the events. In addition, I will also reflect on the true nature of governance types (liberal democracies vs oneman ruled states) and relations between political warfare and types of governance. On this basis, I will investigate applications of Democratic Peace Theory, Constructivism, and Liberalism to the EU and NATO, and Realism and Neo-realism to Russia. Furthermore, I will focus on applications of Institutionalist Theory to all parties when questioning the role of political-military leadership and decisionmaking process.

\section{Internet Survey}

In order to fully understand the drivers of the EU and NATO's failure in countering or undermining Putin's political warfare it will be necessary to go directly to the staffs, branch and division heads, and key leaders working in political affairs, defence planning, intelligence and operation divisions, and also crisis response process in NATO and the EU. A list -based sampling frame, including at least
30 respondents both from NATO and the EU, will be conducted in the second article. The survey will be conducted via the internet to collect data about two main topics: effectiveness of the politicalmilitary leadership of the EU and NATO, and strategic ends-ways-means of the EU and NATO in political warfare and countering political warfare.

\section{Follow-up Interviews with Key Leaders}

The questionnaires will be followed up with a number of in-depth interviews with key leaders such as SACEUR/ DSACEUR, Chief of Staff, Operations and Intelligence Division Heads, Director of Comprehensive Crisis and Management Centre, Chair EU Military Committee, and key leaders in European External Action Service and European Centre of Excellence for Countering Hybrid Threats. These will be designed to gather information regarding effectiveness and shortcomings of the crisis response system, readiness and responsiveness capacity and capabilities of the EU and NATO from respondents "in their own words" rather than official statements.

\section{Round-table Discussions and Panels}

The interviews will be followed by a series of round-table discussions and panels in which civil-military analysts, staff officers, branch and/or division heads, and academics from the EU, NATO, and think tanks (for example Beyond the Horizon, Wilfried Martens Centre for European Studies, the German Marshall Fund of the United States, International Crisis Group, Carnegie Europe, and EGMONT Royal Institute for International Relations) will participate. These will be designed in the last article of this study to gather a comprehensive understanding and evaluations regarding the full spectrum of political warfare waged by Putin, the effectiveness of the countermeasures of the EU and NATO, comparison of the West and Russia regarding deterrence, 
type of governance, and political-military leadership.

Internet survey, follow-up interviews with key leaders, and round-table discussions and panels will provide detailed and up-to-date information and also give a chance to gather tacit knowledge concerning causes and drivers of the EU and NATO's failure in countering political warfare.

\section{RESULTS AND DISCUSSION}

In this part, I will question actions and counteractions of three major actors (the EU, NATO, and Russia) in relation to the full spectrum of political warfare, by applying a multi-disciplinary approach and I will develop a set of measures to be used in the processes of applying or countering political warfare. I believe, this study would be of benefit to scholars in the field of international relations and security, peace studies or conflict resolution. The research would also have practical importance for decision-makers at the national and the supra-national level in Europe and NATO. The following seven hypotheses and the hypothesised model in figure 3 which shows the relationship between the research questions, hypotheses, and theories, and how the further studies work are proposed to be tested in my further studies. In this paper, I aim to identify hypothesis, but since it requires a comprehensive long-term field study on the activities of NATO and the EU, albeit this paper also provides initial findings related to some hypothesis such as $\mathrm{H}_{1-4}$, I plan to test them in my further studies. Next steps of this research will be primarily based on extensive investigation of databases, archival and academic materials; internet survey; follow-up interviews with key leaders; round-table discussions which could gather tacit knowledge on the root causes and drivers of the EU and NATO's failure in countering political warfare.

\section{Proposed Hypotheses and Hypothe- sized Model}

H1: The Russian Grand Strategy since 2000, military transformation, and the Gerasimov doctrine have developed Russian political warfare capacity and capabilities. H2: Liberal democracies acting as "a strategic sponsor" in international organisations are more vulnerable to political warfare employed by one-man ruled countries that are also responsible for their own security. H3: In the framework of political warfare; NATO and the EU's deterrence capacity and capabilities are less effective or sufficient than Russia. H4: In the framework of political warfare; the EU has less effective countermeasures against Russian political warfare on the West. H5:Current decision-making process and political-military leadership in the EU and NATO have significant disadvantages when compared to the autocratic regimes which have uniform command and control structure, and political front. H6: Transformation and enhanced cooperation in defence planning and comprehensive crisis response process between the EU and NATO develops defence capacity and capabilities of these two organisations to conduct political warfare and undermine or counter political warfare.H7: If NATO and the EU reduce the dependency of the US protection and power projection, the two organisations can develop defence capacity and capabilities against external threats and risks.

\section{Evolution of Russian Political Warfare}

Additionally, analysis of the origin and the evolution of Russian political warfare reveal that Russia has been using political warfare not only to gain regional dominance in its buffer-zone, but also challenge the unipolarity of the West, and undermine the role of NATO and the EU (Dickey, 2015; Steward 2015). To illustrate this argument, I would also mention that Russia has sought to strengthen its status as a great power through its sup- 
port for the UN; Brazil, Russia, India, China, and South Africa (BRICS) association; the OSCE, the Shanghai Cooperation Organization; the Eurasian Union and other organizations that support the role of regional powers (Lukin, 2016). In this respect, we should revisit the frozen conflicts such as Abkhazia, South Ossetia and Nagorno-Karabakh, East Ukraine, and Transnistria as evidence and toolkit that Russia redeveloped political warfare capacity and capabilities in order to gain influence in its near abroad neighbouring NATO and the EU borders. The rise of crude oil and natural gas prices since the late 1990s and early 2000s have promoted the resurgence of Russia and its military transformation as utmost important enablers of Russian political warfare and Russian supranationalism, rising in recent years as shown in Figure 4.

The current Russian political warfare strategy, dating back to Bolsheviks and now using hybrid methods which was mainly shaped by Gerasimov (Chief of the Russian General Staff)'s doctrine, asks for a holistic, harmonised approach that comprises political, economic, humanitarian, informational, and other non-military instruments (Suzen, 2014). In conjunction with the Gerasimov doctrine, Russian Federation 2010 Military Doctrine, amended in 2014, conceptualised Russian political warfare. In that document, "simultaneous use of military and nonmilitary mean..." was emphasised. In other words, "Russia is making full use of its diplomatic, informational, military, and economic levers of power" (Dickey, 2015).

On this basis, Putin developed a strategy to use soft power elements in sync with military means (Reisinger \& Golts, 2014). In his speech at the Valdai International Discussion Club's annual meeting in 2014, Putin argued that "the Western system of order threatened Russian interests", and he also urged that "if the existing system of international relations, international law and the checks and balances in place got in the way of these aims, this system was declared worthless, outdated and in need of immediate demolition." Based on his statements, we could hold that, from Russian view, -especially with their enlargement-

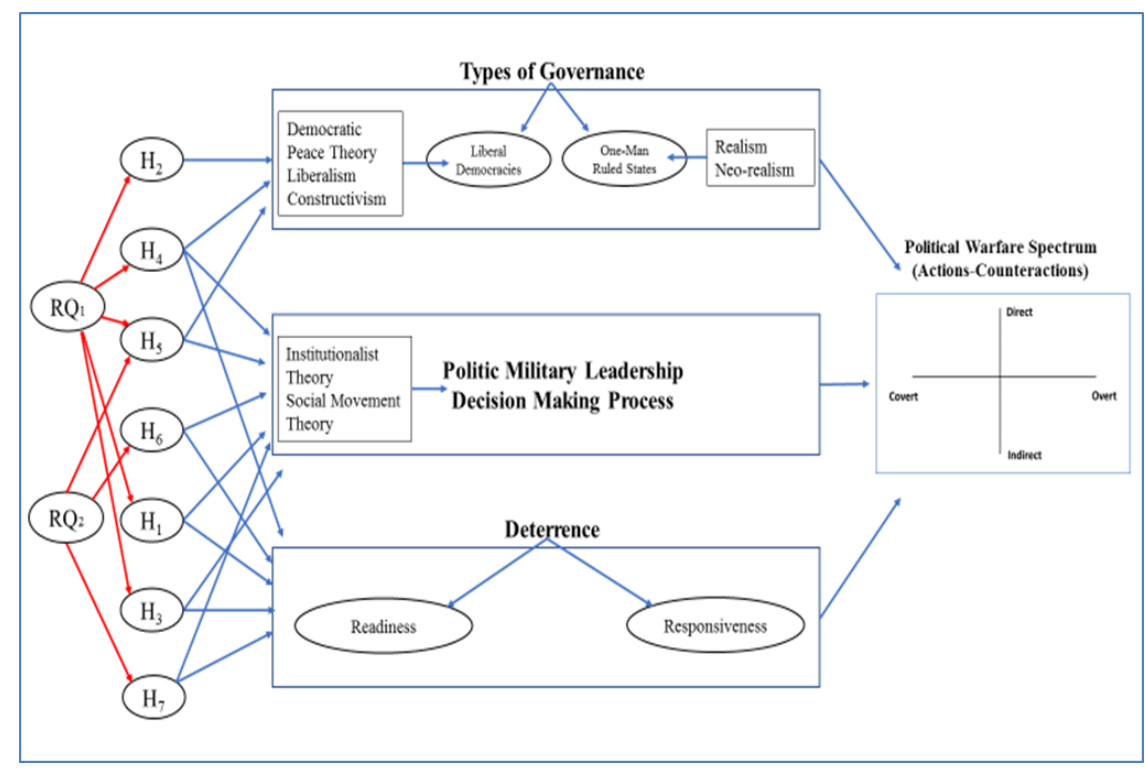

Figure 3. Hypothesized Model for Further Studies

Source: Processed by the author, 2017 
the EU and NATO, and other institutions related to them are threatening Russian security and influence within its "bufferzone" extends in the post-Soviet space.

To me, the Ukraine Crisis is a turning point of Russian political warfare which has been evolving since the 1900s. In 2014, in the following months of violent turbulence in Ukraine, masked Russian Special Forces and Russian backed paramilitary groups, known as "little green men", seized government buildings and key infrastructure in Crimea. In reality, this de facto invasion was not a surprise, but a deliberate and long-term political warfare strategy directed by the Kremlin. A closer look at Russian political warfare reveals that hybrid methods using soft and hard power elements in a mutually complementary and supportive manner are camouflaged by professional propaganda and strategic communication. (Suzen, 2016). This Soviet-style disruption uses "masked warfare" with the addition of computers, social and mass media, and deception operations paralysed the Ukrainian government and the international community, and they could take no action (Dickey, 2015). Furthermore, Rus- sia conducted cyber-attacks against Ukraine (Kofman \& Rojansky, 2015; Pyung-Kyun, 2015), organised ProRussian Ukrainians to manipulate and terrorise Eastern Ukraine. Putin manipulated the outcome of the referendum, which resulted in favour of annexation as well. (Reisinger \& Golts, 2014). Putin did not even hesitate to play the "energy card" at every opportunity by exploiting Ukraine and Europe's energy dependency on Russia (Popescu, 2014). Additionally, Russia has also exported instability to Ukraine through the use of economic warlords, mafia, and criminals whose origins are linked to the late-Soviet era black market (Dickey, 2015).

In the early period of his first term, Putin pursued closer relations with NATO and the EU, as Trenin (2006) summarised, Russia changed its view and left the Western solar system to create their Moscow-centered strategy. At this point, I have to mention the most important driver of this shift, Eurasianism, discussed by some Russian intellectuals such as Aleksandr Dugin and Aleksandr Panarin, who argued: "a version of reintegration of the post-Soviet space into a Eurasian sphere

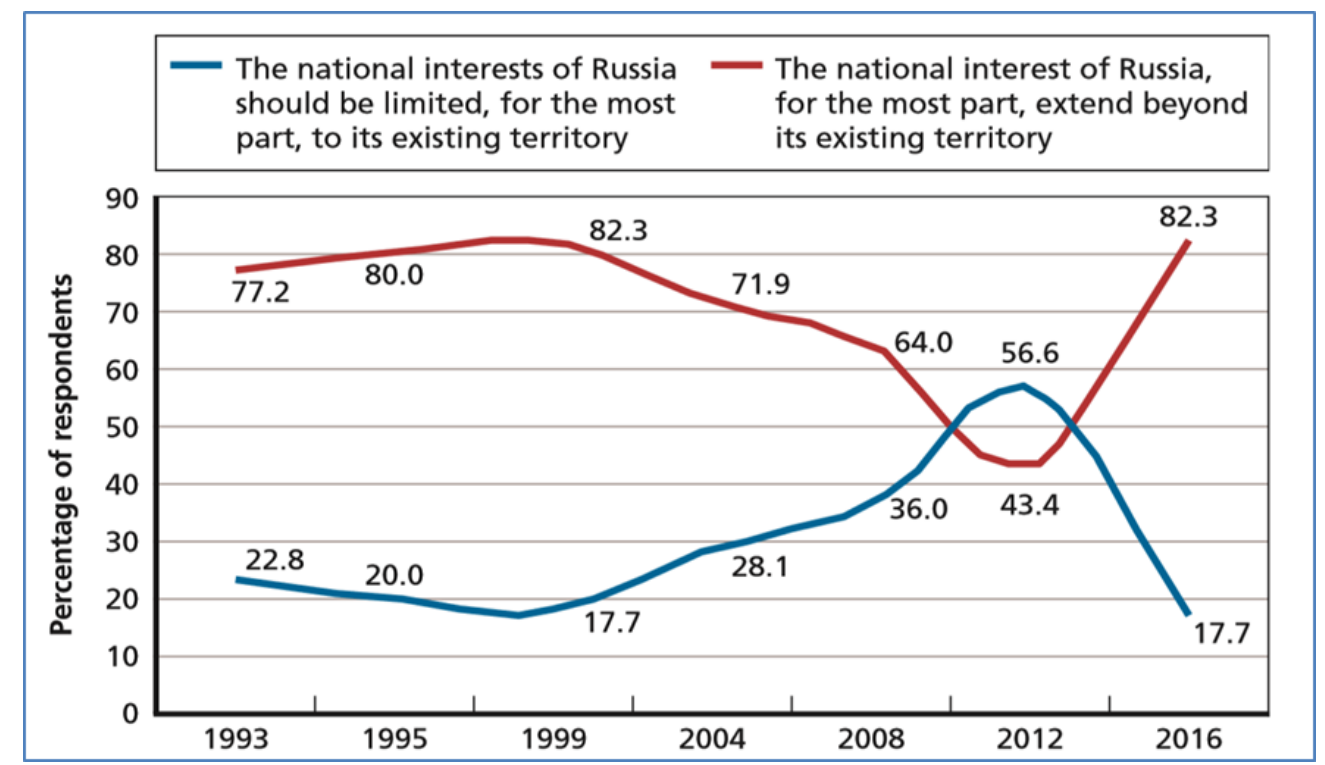

Figure 4. Survey Results on the Scope of Russia's National Interests Source: Rivera, Bryan, Camacho-Lovell, Fineman, Klemmer, \& Emma, 2016 
Available Online at http://journal.unismuh.ac.id/index.php/otoritas

Otoritas : Jurnal Ilmu Pemerintahan, 8 (2), October, 2018, 106

Table 1. A Comparison of Political Warfare Spectrum

Source: Processed by the author, 2017

\begin{tabular}{|c|c|c|c|c|}
\hline $\begin{array}{c}\text { Actions and } \\
\text { Counteractions }\end{array}$ & $\begin{array}{l}\text { Overt } \\
\text { Direct }\end{array}$ & $\begin{array}{c}\text { Overt } \\
\text { Indirect }\end{array}$ & $\begin{array}{l}\text { Covert } \\
\text { Direct }\end{array}$ & $\begin{array}{l}\text { Covert } \\
\text { Indirect }\end{array}$ \\
\hline $\begin{array}{l}\text { Putin's Hybrid Tactics/ } \\
\text { Blurred War }\end{array}$ & $\begin{array}{l}\text { - Energy blackmail } \\
\text { - Economic manipulation } \\
\text { - Strategic communication } \\
\text { - White propaganda } \\
\text { - Mil exercises for deter- } \\
\text { rence } \\
\text { - Military build-up along } \\
\text { the Ukrainian border } \\
\text { - Annexation of Crimea }\end{array}$ & $\begin{array}{l}\text { - Hybrid tac- } \\
\text { tics in East- } \\
\text { ern Europe } \\
\text { - Russian } \\
\text { military build } \\
\text {-up in Black } \\
\text { Sea, Baltic } \\
\text { Sea, Eastern } \\
\text { Mediterrane- } \\
\text { an, and Syria }\end{array}$ & $\begin{array}{l}\text { - Strategic de- } \\
\text { ception } \\
\text { - Psychological } \\
\text { warfare/ infor- } \\
\text { mation opera- } \\
\text { tions } \\
\text { - Black Propa- } \\
\text { ganda } \\
\text { - Diplomatic } \\
\text { support to oppo- } \\
\text { sitions } \\
\text { - Cyber and troll } \\
\text { attacks } \\
\text { - Mobilized lo- } \\
\text { cals } \\
\text { - Armed civilians } \\
\text { - Para-military } \\
\text { forces }\end{array}$ & $\begin{array}{l}\text { - Exporting corruption } \\
\text { - Providing financial } \\
\text { support to Russian- } \\
\text { backed groups } \\
\text { - Political destabiliza- } \\
\text { tion } \\
\text { - Russian trojan horses } \\
\text { such as Turkey }\end{array}$ \\
\hline NATO Counteractions & $\begin{array}{l}\text { - Strategic Communication } \\
\text { (The NATO-Russia Council } \\
\text { meetings) } \\
\text { - Assurance measures in } \\
\text { Eastern Europe and Turkey } \\
\text { * Mil exercises for deter- } \\
\text { rence including high visibil- } \\
\text { ity exercises (eg. Trident } \\
\text { Juncture) } \\
\text { * Enhanced forward pres- } \\
\text { ence } \\
\text { * NATO's VJTF (Very High } \\
\text { Readiness Joint Task Force) } \\
\text { * Enhanced Air Policing } \\
\text { - Adaptation Measures } \\
\text { * New NATO Command } \\
\text { Structure (JFC-A, JSEC, } \\
\text { Cyber Operations Centre, } \\
\text { MNC-NE, MND-NE, MND- } \\
\text { SE, NFIUs) } \\
\text { - Suspension of all practical } \\
\text { cooperation with Russia } \\
\text { (Suspension of NRC, expul- } \\
\text { sion of Russian diplomats) }\end{array}$ & $\begin{array}{l}\text { - Alliance } \\
\text { cohesion } \\
\text { - Partnership } \\
\text { with the } \\
\text { countries in } \\
\text { Russian buff- } \\
\text { er-zone }\end{array}$ & - Cyber defense & $-?$ \\
\hline The EU Counteractions & $\begin{array}{l}\text { - Strategic Communication } \\
\text { - Public diplomacy } \\
\text { - Economic sanctions }\end{array}$ & $\begin{array}{l}\text { - EU-Ukraine } \\
\text { AA/DCFTA } \\
\text { - Lifting arms } \\
\text { embargo on } \\
\text { UKR } \\
\text { - Common } \\
\text { External En- } \\
\text { ergy Policy }\end{array}$ & $\begin{array}{l}\text { - Diplomatic } \\
\text { support to legal } \\
\text { governments }\end{array}$ & $-?$ \\
\hline
\end{tabular}


of influence for Russia" (Dugin, 2012). By this change, there is no doubt that the Ukraine crisis was a dramatic shift away from the West. To this end, it must be noted that Russian way of warfare began initially by Bolsheviks, then kept by Soviets after World War II, evolved throughout the Cold War, and finally revisited by Kremlin, following the turn towards authoritarianism in the 1990s (Zimmerman, 2014). Additionally, from my understanding, Russian involvement in Syria in contrast with Western objectives, and RussiaTurkey rapprochement that enables Russia to use Turkey as a trojan horse within the Alliance should be seen as a part of current Russian political warfare against the West as well.

\section{Application of Theoretical Approaches to Political Warfare}

In this paper, to provide a ground for next studies, I use Steward (2015)'s analytical tool, which extends Kennan (1948)'s overt-covert spectrum with direct-indirect approaches, to assess political warfare actions and counteractions of all parties as shown in Figure 1.

This analytical tool offers to evaluate political warfare actions, counteractions, and also contributes to develop a comprehensive approach in identifying effective practices for increased foreign affairs, security and defence establishments' involvement in political warfare in the future. Table 1 shows us the toolkit and various techniques employed by Russia, which enable a political warfare actor to identify the general areas that can be manipulated in support of a political warfare objective. According to the Table 1, Russian political warfare actions can range from clandestine support of underground Russian-backed groups to all hard and soft instruments available to Russians such as black propaganda, agents of influence, sabotage, economic sanctions, cyber -attacks, and use of force as well; while NATO and the EU counteractions are based on primarily public diplomacy, strategic communication, and limited economic sanctions and assurance measures.

From my perspective, I hardly doubt that the uniform command provides Russia with a kind of situational superiority and an advantage in execution against both the EU and NATO and an opportunity for a systematic concentration of state authority. As group mobilisation or collective action is very important to achieve political warfare objectives (Blackstock, 1964; Seabury and Codevilla, 1989), in my further studies, I will apply Social Movement Theory to political warfare actions and counteractions of all parties to understand the collective dynamics of the events. Additionally, I will discuss the true nature of governance types (liberal democracies vs one-man ruled states) and its relations with political warfare. To achieve afore-mentioned goals, I will investigate applications of Democratic Peace Theory, Constructivism, and Liberalism to the EU and NATO, and Realism and Neo-realism to Russia. Furthermore, I will focus on applications of Institutionalist Theory to all parties when questioning the role of political-military leadership and decision-making process.

\section{CONCLUSION}

This article, as the first of three articles in the series, proposed a conceptual framework and some supporting models for policymakers, planners, and practitioners to better understand the new form of political warfare. Taking the new form of political warfare currently waged by Putin against the West into consideration, it could be argued that EU and NATO's response to Putin's protracted hybrid strategy has been ineffective. From my point of view, the EU and to some extent NATO's responses based on appeasement encourage Putin's aggression. In other words, NATO and EU lack strategy, policy, and the organisational framework for both implementing an effective politi- 
Available Online at http://journal.unismuh.ac.id/index.php/otoritas

Otoritas : Jurnal Ilmu Pemerintahan, 8 (2), October, 2018, 108

cal warfare strategy and countering thereof.

Putin's political warfare affects the Western security and stability in three ways: a) it destabilizes the global security status quo, b) it threatens the EU's and NATO's solidarity and cohesion and undermine their roles in the international system, c) it sets an example for other possible adversaries how political warfare could be a valuable and effective way of war to target liberal democracies without triggering any armed conflict.

Although I will go in details in my further studies, based on the initial findings of this paper, I would like to highlight the following points which could bridge the gap between the conceptual framework presented in this paper and practice. First, The EU and NATO must keep dialogue channels with Russia open. Second, rather than limiting NATO and EU enlargement demonstrating the rights of former Soviet republics to secure their future, NATO and the EU must use a wide range of military and political tools to deter Russian aggression and preserve the liberal order, and the last to counter Russian efforts to divide and freeze the EU and the Alliance, the EU and NATO need for defence building or military transformation process in some particular areas such as decision-making, crisis response and operation management, and concept of operational art in order to launch and counter political warfare.

\section{ACKNOWLEDGEMENT}

I am grateful to each of the members of Beyond the Horizon International Strategic Studies Group with whom I have had the pleasure to work. They have provided me extensive personal and professional guidance and insights about both scientific research and life in general.

\section{REFERENCES}

Art, R. J. (2009). "The Fungibility of Force," in The Use of Force: Military Power and International Politics, ed. Robert J. Art and Kenneth N. Waltz. New York: Rowman and Littlefield Publishers.

Blackstock, P. W. (1964). The strategy of subversion: Manipulating the politics of other nations. Chicago: Quadrangle books.

Boot, M. \& Doran, M. (2013). "Politicalwarfare: Policy Innovation Memorandum No. 33," Council on Foreign Relations, 1.

Clausewitz, C. V. (1982). On War trans. New York, N.Y: Penguin Books.

Codevilla, A. (2009). Political Warfare: Means for Achieving Political Ends. In Strategic Influence: Public Diplomacy, Counterpropaganda, and Political Warfare, ed. Michael Waller J. Washington, D.C.: Institute of World Politics Press.

Congressional Research Service, NATO: Response to the Crisis in Ukraine and Security Concerns in Central and Eastern Europe, pp. 1, 2014.

Dickey, J. V. (2015). Russian Political Warfare: Origin, Evolution, and Application. Naval Postgraduate School Thesis, California.

Dexter, B. (1950). Clausewitz and Soviet Strategy. Foreign Affairs (October 1950): 1-4. http:// www.foreignaffairs.com/ articles/70846/byron-dexter/ clausewitz-and-soviet-strategy.

Dugin, A. (2012). Eurasian Keys to the Future, The Fourth Political Theory, May 2012.

Gray, C. S. (2009). Fighting Talk: Forty Maxims on War, Peace, and Strategy. Washington, D.C: Potomac Books. 
Hill, F. \& Gaddy, C. (2013). Mr. Putin: Operative in the Kremlin, Washington, D.C.: Brookings Institution Press.

Hoffman, F. (2014). On Not-So-New Warfare: Political Warfare vs. Hybrid Threats," War on the Rocks, July 28, $2014 . \quad$ http:// warontherocks.com/2014/07/on -not-so-new-warfare-politicalwarfare-vs-hybridthreats/.

Kennan, G. (1948). The Inauguration of Organized Political Warfare, April 30, 1948, State Department.

Kofman, M. \& Rojansky, M. (2015). A Closer Look at Russia's "Hybrid War". Kennan Cable, No.7, Wilson Center.

Lukin, A. (2016). Russia in a Post-bipolar World. Survival, 58(1), 91-112.

Oliker, O., Crane, K., Schwartz, L.H., and Yusupov, C. (2009). Russian Foreign Policy: Sources and Implications. United States: Rand Corporation.

Popescu, A.I.C. (2014). Observations Regarding the Actuality of the Hybrid War. Case Study: Ukraine. Strategic Impact No.4/2014.

Pyung-Kyun, W. (2015). The Russian Hybrid War in the Ukraine Crisis: Some Characteristics and Implications. The Korean Journal of Defense Analysis, 27(3), 383-400.

Radin, A., \& Reach, C. (2017). Russian views of the international order. United States: Rand Corporation.

Ratsiborynska, V. (2018) Russia's hybrid warfare in the form of its energy maneuvers against Europe: how the EU and NATO can respond together?. NATO Review, No.147, June 2018.

Reisinger, H. \& Golts, A. (2014). Russia's Hybrid Warfare. Research Paper, NATO Defense College, No.105.
Rivera, S. W., Bryan, J., Camacho-Lovell, B., Fineman, C., Klemmer, N., \& Raynor, E. (2016). Levitt Poll: The Russian Elite 2016-Perspective on Foreign Policy and Domestic Policy. Clintion, N.Y: Hamilton College.

Seabury, P. and Codevilla A. (1989). War: Ends and Means. New York: Basic Books.

Smith, P. Jr. (1989). On Political War, 1st ed., National Defense University Press, 30.

Steward, A. L. (2015). Political Warfare and Contentious Politics. Naval Postgraduate School Thesis, California.

Sun, W. \& Griffith, S.B. (1971). Sun Tzu the Art of War, Translated (from the Chinese) and with an Introduction by Samuel B. Griffith, Etc. (London: Oxford University Press).

Suzen, H. (2014). The Role of Gerasimov Doctrine in the Rise of Russian Armed Forces. Journal of TUR Army War College, 32(5).

Suzen, H. (2016). Fixed Structures and Functionalities vs the Philosophy of Modular Design. Presented at International Conference on Military and Security Studies, Istanbul 2016.

Trenin, D. V. (2006). Russia Leaves the West, Foreign Affairs, July/August 2006.

Trenin, D. V. (2011). Post-Imperium: $A$ Eurasian Story. Washington, D.C.: Carnegie Endowment for International Peace.

Zimmerman, W. (2014). Ruling Russia: Authoritarianism from the Revolution to Putin. Princeton and Oxford: Princeton University Press, 220-266. 